\title{
ANALYSIS OF ASSOCIATIVE SOCIAL INTERACTION PROCESSES BETWEEN THE STUDENT COUNCIL IN JUNIOR HIGH
}

\author{
Abdul Aziz \\ SMP Islam Ashabul Kahfi Pontianak \\ Email : azizpensos12@gmail.com
}

\begin{abstract}
The study aims to determine the associative cooperation between board and accommodation OSIS SMP Islam Ashabul Kahfi Pontianak in West Borneo period 2015-2016. The method used is descriptive with problem solving procedures investigeted by describing or depicting the state of the subject or object of research. In the study sample are seven members of the total board OSIS twenty four members. The analysis showed that the cooperation between board OSIS has worked well for the cooperation ehich is always enhanced by the whole OSIS and coaching are continually done by coach OSIS SMP Islam Ashabul Kahfi Pontianak, although still les than perfect because of several obstacles that accur within board OSIS.
\end{abstract}

\section{Keywords: Theory of Cooperation, Social Interaction, OSIS Board}

Social interaction is a general form of social processes, because social interaction is a key condition for social activities. Social interaction will occur if it meets two conditions, namely social contact and communication. If social contact and communication are fulfilled and run well, good social interaction is formed, good social interaction takes the form of associative social interaction. Associative social interactions that lead to unity, in the process between individuals or groups with one another must understand each other and realize that they have the same interests to achieve a common goal. As explained by Nina (2012: 96) associative social process is "a process that occurs, where there is mutual understanding and mutual cooperation between individuals or groups with one another, and this process results in achieving common goals".

According to Soerjono (2014: 55) social processes are "interrelated ways that can be seen if individuals and groups meet each other and determine the system and form of the relationship or what will happen if the changes that cause shaky ways life that already exists ".

In the life of the community it is also necessary to have a forum that can be used to channel the aspirations of views, thoughts and opinions for the achievement of common goals, therefore an organization is formed. Many forms of organization in society both legal entities and nonlegal entities, but basically the 
purpose of the formation of these organizations is to prosper the community.

Likewise with organizations in the school environment, where the purpose of forming student organizations, OSIS is channeling the aspirations of students to school leaders such as school principals, vice-principals, teachers and so on. Not always decisions made by school leaders can be accepted by students, so the means to channel these aspirations through this organization is conveyed. The student council organization is very important in our lives and is pervasive in community life and the school environment, because in reality most people live in organizations and spend their lives as members of organizations (social, work, school, etc.).

Indeed, sometimes we see that organizations can run smoothly, efficiently and quickly and are responsive to human needs and sometimes also can disturb or confuse us. However, the organization can at least achieve its objectives efficiently and effectively if the ability of technical skills and managerial skills can be applied well into a solid unit which is a good collaboration to achieve organizational goals.

Based on the pre-research results conducted by researchers through interviews with Mr. Andrianto, S.Pd. as the OSIS Trustees at Pontianak's Ashabul Kahfi Middle School, on Monday December 92018 at 08: 0009: 00 WIB at Pontianak's Ashabul Kahfi Middle School. Stating that in an organization it must be based on good and solid cooperation between the members, so that the organization will run well in accordance with the goals and ideals and for mutual progress.

Researchers conducted preresearch on Monday 14 - Saturday 19 December 2018, researchers conducted pre-research that coincided with Class Meeting activities that were being carried out by the Islamic Boarding School Student Boarding School, Ashabul Kahfi Pontianak Pontianak Period 2018/2019 and was accompanied by the Student Council Counselor, Ashabul Kahfi School, Pontianak, namely Mr. Andrianto S.Pd. After the researchers conducted an observation in the field during the Class Meeting, there were indeed many unfavorable collaborations, when the activities took place, such as Volleyball competition between classes, there were several OSIS who became the Coordinator or the person in charge of the match instead of being around. field to monitor the course of the match, while fellow student councilors do not want to help replace friends who are not in the field. Not only in the Volly match, but in the Batik Design and Table Tennis competition also did not go well, other than that the availability of match equipment was not prepared by the student council committee who became the organizing committee, so the match could not run properly.

Apart from that the commissions did not go well between the coordinators of the competition, the coordinators or the organizers of the competitions did not communicate with each other they seemed to be walking on their own, so that when there were problems in the implementation of the competition such as lack of equipment as supporters of the competition there 
was no alertness and activeness to directly take and provide equipment. As a result, the competition is often not timely and in accordance with the predetermined agenda of the activity does not look so cornering, but what happens in the field even the race coordinator runs independently do not coordinate with each other between the coordinator. Therefore, there are not all activities that can run well and

\section{RESEARCH METHODS}

The method used is descriptive method. Problem-solving procedures that are investigated by describing or describing the state of the subject or object of research (a person, institution, community and others) at the present time based on the facts that appear, or as they are. And matters relating to this motede include the following.

The location of this research is in the Ashabul Kahfi Islamic Middle School Pontianak. J1. National Awakening Kel. Batu Layang Kec. North Pontianak.

The instrument in this qualitative research is the researcher himself. As an instrument, researchers must have readiness when conducting research starting from the beginning of the study until the end of the research process.

Data Sources: (1) Primary data sources Primary data sources are data sources obtained directly through interviews with informants. According to Satori and Komariah (2011: 145), primary data sources are "Data sources that directly provide are successful due to the lack of cooperation between the race coordinators.

Based on this background, researchers are interested in conducting further research in order to examine the Process of Associative Social Interaction Between the Student Council of Islamic Junior High School Ashbul Kahfi Pontianak.

data to data collectors". The informants in this study were the Islamic Boarding School Students of Islamic Middle School Ashabul Kahfi Pontianak in the 2018-2019 period. (2) Secondary data sources. Secondary data sources are data obtained indirectly from sources such as student council activities and evaluations from management and student council coaches.

In this research, several data collection techniques will be used, namely: (1) Interview (2) Observation

(3) Documentation Study.

1. Data reduction. Reducing data means summarizing, choosing the main points, focusing on the important things, looking for themes and patterns and removing unnecessary. Thus the reduced data will provide a clearer picture, and make it easier for researchers to do further data collection, and look for it if needed. In this case the researcher focused on the pattern of collaboration and interaction between the student council board of the Ashabul Kahfi Middle School Pontianak.

2. Data display. At this stage many researchers are involved in the presentation or appearance of the data collected and analyzed 
beforehand. Presentation of the data is directed so that the resulting reduction data is organized, arranged in a relationship pattern so that it is easier to understand and plan further research work. Presentation of data display is intended to make it easier for researchers to be able to see the overall picture or certain parts of research data. The data is then sorted and set aside for sorting according to the group and arranged according to similar categories to be displayed so that it is consistent with the problem at hand, including temporary conclusions obtained at the time of data reduction. In presenting the data, the researcher was directly involved with the OSIS activities of the Pontianak Islamic Middle School, Ashabul Kahfi, among others: a relaxing walk and a flag ceremony every Monday on April 11, 2019.

3. Decision making and verification. Verification is an activity carried out during the research both at the beginning of entering the research site, retrieval of research data until the time of presenting data. The data obtained were verified from an insulated data source used in this qualitative study. The more data obtained, the more clear the conclusions the data obtained from the problem at hand.

Testing the validity of the data: (1) Extension of observations, The purpose of this extension of observation is that the relationship between researchers and resource persons will be increasingly formed, more familiar and open, and trustworthy so that no information is hidden anymore. The time needed to extend the observation depends on the depth, breadth and certainty of the data the researcher found. (2) Observations made to complete the data in this study carried out until August, which coincides with the activities of August 17 by holding competitions held by the board of student council of Pontianak Ashabul Kahfi Middle School. (3) Triangulation, based on the above opinion, the researcher compares each data obtained from observational data, study documentation data, and interview data. For the type of data obtained based on observations and interviews conducted with reference to the observation guidelines and interview guides that will be developed. The results of observations such as observation lists and interviews are processed to describe qualitatively as facts found in the field. While the document is used to support and complete the description before it is processed with triangulation research. The types of triangulation used in this study are: 1) Triangulation of sources. 2) Triangulation of techniques. 3) Time travel. Triangulation of sources, the source used as a benchmark in the results of the study was the results of interviews with informants in this case the board of student council of Islamic Junior High School Ashabul Kahfi Pontianak as the informant. In addition to interviews, other sources used were OSIS activities such as, casual walks and flags every Monday also became a source of triangulation in this study in order to find out the validity of the data and in accordance with the problems examined in the field. 


\section{RESEARCH RESULTS AND DISCUSSION \\ Research Results}

Observation data in this study were obtained based on observations made by the researchers themselves during 2 observations on 9 and 11 April 2019 at 07: 00-10: $00 \mathrm{WIB}$, to the management of Islamic Boarding School Islamic Boarding School Ashabul Kahfi Pontianak, where each conducted observation activities and researchers conducted in-depth about associative social interaction in the form of cooperation and accommodation where researchers conducted research directly as outlined in the form of observation.

Observations made by researchers namely on 9 and 11 April 2019 , this was done by researchers after going through various stages of approach, approval, and preparation in its implementation. In addition, researchers also filter and present data so as not to deviate from the focus of research and the main target in this thesis is about "Analysis of the associative social interaction process between the management of Islamic boarding school Islamic Middle School Ashabul Kahfi Pontianak". The findings are as follows.

Observation Findings on April 9, at 07: 00-10: 00 WIB. In the management of OSIS there must be fields that carry out OSIS work program for 1 year of management, in this case the physical fitness field carries out its work program, one of which is a relaxing walk every 2 weeks, involving all student council officials and all students and the teacher council Ashabul Kahfi Islamic Middle School Pontianak.
Casual walking activities are carried out every 2 weeks by the management of Islamic Junior High School student OS Ashabul Kahfi to maintain the health of all administrators and students, which in this case the coordinator of their activities is Riky Priyanto, while the field of physical fitness is not only the field of physical fitness that works in this activity but also in collaboration with all other student council officials also collaborated in this activity, especially in maintaining the line of students who are running so that it is organized and does not disturb traffic around the National Awakening and Sinar Pelita roads, in order to maintain order, every 15 people a line was placed by one student council official to maintain order. This activity was carried out at 07.00$10.00 \mathrm{WIB}$, the leisurely walk started from the National Awakening road and turned to the Sinar Pelita road back to School which took approximately an hour and a half in carrying out the leisurely walk. After returning to the student council board of students and students of Islamic Middle School Ashabul Kahfi Pontianak take a short rest after that students are invited to join extracurricular activities that they enjoy such as playing volleyball, table tennis and badminton until they end at 10:00 WIB.

Observation Findings on 11 April 2019 At 06: 45-08: 00 WIB. At 06:50 IWST, the school entrance bell rang, the student council immediately rushed over to the class that had been appointed a few days earlier as the flag ceremony officer on Monday, and the person responsible for calling 
the flag ceremony officer from the designated class was the student council official nation and state.

After the flag ceremony officer was summoned and dropped out to the field to carry out the flag ceremony after that the student council also told all students of the Islamic Middle School Ashabul kahfi Pontianak to go down to the field assisted by the teacher council to take part in the flag ceremony on Monday.

After all had been done in the

field both the officials and participants of the ceremony were ready before the flag ceremony began, in the implementation of the flag ceremony all the student council organizers were placed in each class row to maintain the enjoyment of the flag ceremony so that participants would participate calmly and with wisdom. Monday's flag ceremony was attended by approximately 190 students and also followed by 5 council of teachers. The flag ceremony was dreamed by the headmaster of the Islamic Middle School Ashabul Kahfi Pontianak, Mr. Juraiji, S.Pd.I, as the coach for the Monday flag ceremony, and the last flag ceremony at 07.30 WIB.

Observational data in this study were obtained based on observations made by the researchers themselves during 2 observations on 9 and 11 April to the management of Islamic Boarding School Islamic Junior High School Ashabul Kahfi Pontianak, where each made observations and activities, researchers conducted in-depth about associative social interactions in the form of accommodation in where researchers conduct research directly as outlined in the form of observations.

Observations made by researchers namely on 9 and 11 April 2019, this was done by researchers after going through various stages of approach, approval, and preparation in its implementation.

In carrying out activities carried out by the student council management sometimes face obstacles that occur in the student council board, which is related to cooperation that is less compact because some student council organizers have different views, so the activities sometimes run long.

As with the observation findings on April 9, 2019 which coincided with the routine activities of two weeks, namely the leisure walk activities which became the permanent agenda of the student council, in the implementation of experiencing a few obstacles, in the implementation of class meting activities there were some student council organizers who were a little forced to assist students and keep the ranks in order during the activity, when something like that happens usually the other student council officials ask for help from the teacher who is present to ask the student council officials who are lazy to want to work together, small things like that sometimes make the activity run a little slow from time which is determined.

\section{Interview result}

The following will be presented the results of interviews conducted by researchers with 9 student council officials on 12 and 13 April 2019 at 08.00-10.00 WIB, which researchers took to conduct 
research at the Ashabul Kahfi Islamic Middle School in Pontianak. The results of the interview are as follows. 1) Since when did you join the student council?

Nuraini: The board of student council of Islamic Boarding School Ashabul Kahfi Pontianak joined to become student council of the Student Council on September 72019 as well as the appointment of other student council fields.

2) Why are you interested in becoming a student council administrator?

Akmal Shaleh: Student of Islamic Boarding School Islamic Middle School Ashabul Kahfi Pontianak interested in becoming Student Council of Student Council is looking to experience and learn in organizing at the junior high school level and learn to work well together

3) What is the form of cooperation between the student council officials? Usfiatul: From the discussion of the student council officials in the interview session that the collaboration between the student council is in the form of mutual cooperation, please help and help one another.

4) Do you often find difficulties in carrying out your duties as student council student?

Bambang Fajar: In carrying out the task that the management of the student council is not too difficult, but sometimes there are some student council officials who do not understand their tasks.

5) How do you maintain cooperation between the student council officials? Alfil Khairussaleh: To maintain good cooperation between OSIS teachers, which is always doing activities together, namely chatting together, going to the canteen together with the student council and with other students, and doing sports activities such as playing volleyball together for the student council with the Ashabul Kahfi Islamic Middle School Pontianak students. (interview Tuesday, April 12, 2019)

\section{Discussion}

Based on the results of observations made by researchers twice on the informant about social interaction in the form of cooperation between the management of the Islamic Junior High School student OS Ashabul Kahfi Pontianak showed that the informant had done social interaction skills well, especially the initial level of cooperation skills carried out when carrying out leisure walk activities and Monday's flag ceremony.

In this case all aspects went well, as well as the field of national and state life that had carried out the program, namely the flag ceremony every Monday and the appointment of the flag ceremony officer, in the implementation of each student council board worked according to their duties as administrators even though it was not their field, but they willing to do it even though sometimes a little forced because there are some student council officials who are sometimes lazy to guard the flag ceremony rows as well as the officials from each class who are sometimes reluctant to become officers so that they must involve the teacher to appoint ceremonial officials.

On Friday 9 April 2019 observation at 07.00-10.00 WIB, there was a relaxing walk with all the 
students of Pontianak Islamic Ashabul Kahfi Middle School, where the relaxing walk became an OSIS work program especially in the field of physical fitness which was carried out every 2 weeks every day Saturday by involving all students and all student council officials and teachers who were present that day.

Then observations on Monday, April 11, 2019 at $6: 45$ to $8: 00 \mathrm{pm}$, clearly visible forms of cooperation between members, such as they prepare the flag ceremony officers on the previous day to become Monday flag ceremony officers which in this case are responsible, namely the field national and state life and assisted by other student council organizers during the flag ceremony.

The casual walk and flag ceremony every Monday which became the routine agenda of the Islamic Boarding School student board of Islamic Boarding School Ashabul Kahfi Pontianak was running well even though there were a few obstacles, but the obstacles were not too disturbing so that the activity could continue to run according to the routine agenda of the student council.

On April 9, 2019 observation at 06.45-16.00 WIB, on Saturday, it was seen that the social interaction of accommodation in the form of leisure walk activities carried out by the student council officials every two weeks could be carried out well, there were no significant problems, although in the implementation there were indeed few issues such as the order of the students who took the relaxing walk were a bit messy due to the lack of supervision from the student council officials to keep each row neat and not disturb the existing traffic. In this case all the student council officials were instructed by the student council president and by the coach to do their job properly for the smooth running of activities that have become the OSIS work program of Islamic Middle School Pontianak Ashabul Kahfi School.

Furthermore, based on the results of interviews conducted by researchers to the management of Islamic Boarding School Islamic Boarding School Boarder Ashabul Kahfi Pontianak, getting information from all informants who revealed the accommodation problem is "lack of cohesiveness within the student council, so that this sometimes becomes an obstacle in carrying out work programs and routine activities. student council".

Problems may be common and may not be avoided because of the dozens of management must have different thoughts, in line with the results of interviews with student council officials who revealed that if there is a difference of opinion then the council coach and chairman of the OSIS "provides understanding and guidance that differences of opinion within an organization or the group is normal, but how to find a middle ground and positive things that can be learned", through the information obtained by researchers through interviews with the student council officials, it is clearly implied that the association of associative social interaction in the form of good accommodation between student council board of Islamic Middle School Ashabul Kahfi Pontianak, this is in line with the theory of accommodation by (Gillin in July 2011:21) is an understanding used by 
sociologists to describe a process of social relations which is the same meaning as the understanding of adaptation used by biologists to find

\section{CONCLUSIONS AND SUGGESTIONS Conclusions}

Based on the results of research and discussion that researchers have done, the conclusions in this study are as follows: Associative social interaction in the form of collaboration based on observations and interviews conducted by researchers about social interactions in the form of cooperation between the management of Islamic Boarding School Student Islamic Boarding School Ashabul Kahfi Pontianak shows that it has been running good and running harmoniously, as evidenced by the activities carried out by the student council organizers namely relaxing walking activities and the flag ceremony on Monday. The activity was to foster students so that the spirit of nationalism and the love of the motherland, as well as for the student council officials could increase their cooperation by helping one another to train students who were ceremonial officers. Associative social social interaction in the form of accommodation does not occur significant problems, although in its implementation there are indeed a show in a process where living things adjust themselves to the natural surroundings.

few problems but it does not necessarily interfere with all work programs that have been planned or that have been carried out by the management of Islamic Junior High School Boarder Ashabul Kahfi Pontianak.

\section{Suggestion}

Based on the conclusions presented above, the following suggestions were put forward: To realize associative social interaction in the form of cooperation and accommodation for the management of Islamic Boarding School Islamic Boarding School Islamic Boarding School Pontianak, it is expected that all student council officials can increase awareness and a sense of volunteerism through routine activities that have been carried out and realize that humans are social beings who cannot live alone, so humans must not discriminate with one another. For all students of Islamic Boarding School Islamic Middle School Ashabul Kahfi must further enhance the sense of brotherhood solidarity so that in carrying out their duties and responsibilities as student council officials can be based on mutual cooperation and the principle of brotherhood between fellow OSIS officials so that the planned program can run well and be successful. 


\section{REFERENCE}

Basrowi. (2005). Pengantar Sosiologi. (Cetakan Ke-1). Bogor: Ghalia Indonesia.

Hadari Nawawi. (2007). Metode Penelitian Bidang Sosial. Yogyakarta: Gadjah Mada University Press.

Imam. (2014). Metode Penelitian Kualitatif Teori dan Praktik. Jakarta: Bumi Aksara

Juli. (2011). Hubungan Sosial Asosiatif dan Disosiatif. (Cetakan ke-2). Jakarta: CV.Rama Edukasitama
Nina Winangsih. (2012). Sosiologi Sebagai Akar Ilmu Komunikasi. (Cetakan ke-1). Bandung: Simbiosa Rekatama Media

Satori, Djam'an dan Komariah, A'an. (2011). Metode Penelitian Kualitatif. Bandung: Alfabeta Sholihin $2012 \quad$ Materi Keorganisasian. (online) (diakses 15 Januari 2016)

Soekanto, Soerjono dan Sulisyowati, Budi. (2014). Sosilogi Suatu Pengantar. (Cetakan ke-46). Jakarta: Rajawali Pers 